\title{
The Influence of Climate Change on the Environment of the Mirzachul Natural Territory
}

\author{
Meliboy Normatovich Kamolov \\ Associate Professors Jizzakh State Pedagogical Institute \\ Sunnatillo Ibragimov \\ Master Student Tashkent State Pedagogical University
}

\begin{abstract}
BSTRACT: This article discusses the impact of climate and its components on environmental landscapes in the Mirzachul natural region. Due to this, in December and January the air temperature decreased to -340S (Mirzachul), -320S (Nurata, Jizzakh), -290 C (Forish). However, the average temperature in January is not lower than $-0.10 \mathrm{~S}$ (Forish), $-0.60 \mathrm{~S}$ (Jizzakh), $-1.60 \mathrm{~S}$ (Nurota).
\end{abstract}

EY WORDS: Mirzachul natural region, climate, air temperature, relative humidity, wind, precipitation, environment, landscape.

\section{NTRODUCTION}

Long-term data from 8 meteorological stations and posts were used to describe the climate of the Mirzachul natural region. Due to the fact that the Mirzachul natural region is surrounded by the Kyzylkum Desert on the northwest side, hot air flows come from the desert during the summer months. The average July temperature is $310 \mathrm{C}$ in Ayoqogitma, close to the natural geographical region in the eastern part of the Kyzylkum desert, 29.40C in Forish, 28.60 C in Jizzakh and $26.70 \mathrm{C}$ in Syrdarya. This means that the average July temperature from the Kyzylkum Desert to the central part of Mirzachul varies by 4.30C. Such differences are also observed from May to September.

Due to the fact that the Mirzachul natural geographical area is surrounded by a plain on the north side, the cold air currents from the north of the Arctic-Siberia come unimpeded. Due to this, in December and
January the air temperature decreased to $-340 \mathrm{~S}$ (Mirzachul), -320S (Nurata j / x, Jizzakh), -290 C (Forish). However, the average temperature in January is not lower than -0.10S (Forish), -0.60S (Jizzakh), 1.60S (Nurota $\mathrm{j} / \mathrm{x}$ ). This indicates that there will also be many warm days in the winter months in the area. Occasionally, in January, the temperature rose to +

230 S (Mashiquduq) and + 220S (Jizzakh).

For most of the year, high air temperatures cause low relative humidity. In the Kyzylkum desert in the western part of the Mirzachul natural region, the average relative humidity is less than $50 \%$, and in June and July it drops to 20-23\% (Ayoqogitma, Mashikuduk). Relative humidity will increase slightly towards the foothills and will rise to $24 \%$ in Forish and $32 \%$ in Jizzakh in July. This month, it is $46 \%$ at Mirzachul station and $50 \%$ at Syrdarya (see Table 1.1). 
Table 1.1

Average monthly and annual changes in relative humidity, (\%)

\begin{tabular}{|c|l|c|c|c|c|c|c|c|c|c|c|c|c|c|}
\hline T/p & Station & I & II & III & IV & V & VI & VII & VIII & IX & X & XI & XII & year \\
\hline 1 & Ayoqogitma & 78 & 70 & 64 & 50 & 33 & 23 & 20 & 21 & 25 & 39 & 58 & 76 & 46 \\
\hline 2 & Mashiquduq & 78 & 73 & 64 & 51 & 33 & 22 & 20 & 28 & 29 & 39 & 62 & 76 & 48 \\
\hline 3 & Forish & 72 & 70 & 70 & 60 & 45 & 29 & 24 & 27 & 29 & 43 & 59 & 71 & 50 \\
\hline 4 & Jizzakh & 77 & 75 & 73 & 63 & 50 & 35 & 32 & 34 & 37 & 50 & 65 & 76 & 56 \\
\hline 5 & Mirzachul & 77 & 75 & 76 & 66 & 57 & 47 & 46 & 50 & 53 & 60 & 71 & 80 & 63 \\
\hline 6 & Syrdarya & 85 & 84 & 76 & 70 & 59 & 49 & 50 & 58 & 61 & 68 & 74 & 84 & 68 \\
\hline
\end{tabular}

The distribution of precipitation also increases in the Kyzylkum region to the east and to the mountains. In the eastern part of the Kyzylkum, the average annual precipitation at the Ayoqogitma station is $112 \mathrm{~mm}$, in Mashikuduk $137 \mathrm{~mm}$, in Nurata $237 \mathrm{~mm}$, and in Forish $366 \mathrm{~mm}$. This means that in the western part of the Mirzachul natural geographical region, 2.5-3.0 times more precipitation falls in the eastern part than in the desert (see Table 1.2).

Table 1.2

Average monthly and annual precipitation, $\mathrm{mm}$

\begin{tabular}{|l|l|c|c|c|c|c|c|c|c|c|c|c|c|c|c|}
\hline № & Station & $\mathrm{m} / \mathrm{b}$ & $\mathrm{I}$ & $\mathrm{II}$ & $\mathrm{III}$ & $\mathrm{IV}$ & $\mathrm{V}$ & $\mathrm{VI}$ & $\mathrm{VII}$ & $\mathrm{VIII}$ & $\mathrm{IX}$ & $\mathrm{X}$ & XI & XII & year \\
\hline 1 & Ayoqogitma & 184 & 12 & 15 & 20 & 21 & 12 & 5 & 2 & 0,5 & 1 & 5 & 8 & 11 & 112 \\
\hline 2 & Mashiquduq & 199 & 16 & 18 & 26 & 23 & 13 & 4 & 2 & 0,4 & 1 & 6 & 12 & 16 & 137 \\
\hline 3 & Nurata farm & 380 & 20 & 27 & 41 & 40 & 22 & 4 & 0,2 & 0,3 & 1 & 12 & 34 & 35 & 237 \\
\hline 4 & Forish & 525 & 38 & 41 & 60 & 47 & 25 & 6 & 1 & 1 & 3 & 19 & 34 & 41 & 316 \\
\hline 5 & Jizzakh & 392 & 45 & 48 & 69 & 56 & 28 & 8 & 1 & 1 & 2 & 21 & 41 & 46 & 366 \\
\hline 6 & Mirzachul & 276 & 32 & 33 & 48 & 42 & 27 & 9 & 2 & 2 & 3 & 18 & 30 & 30 & 276 \\
\hline 7 & Yangier & 224 & 37 & 42 & 63 & 59 & 34 & 9 & 3 & 1 & 3 & 24 & 32 & 33 & 340 \\
\hline 8 & Syrdarya & 204 & 41 & 40 & 59 & 50 & 27 & 6 & 2 & 1 & 1 & 24 & 33 & 40 & 324 \\
\hline
\end{tabular}

The productivity of pasture grasses in the natural geographical area of Mirzachul depends on the amount of precipitation and the time of precipitation in the spring. According to the Jizzakh meteorological station, the highest rainfall was 575 $\mathrm{mm}$ in a year and $147 \mathrm{~mm}$ in a dry year [20]. This means that in rainy years it rains four times as much as in a dry year. Undoubtedly, during the rainy years, large amounts of water fell into the Mirzachul natural geographical region from the rivers of the Syrdarya, Sangzor and Nurata mountains, forming lakes instead of salt marshes and swamps, and in dry years they turned into salt marshes. This can also be seen by comparing data from the 2003 rainy years to the 2007 drought years (see Table 1.3). 
Table 1.3

Precipitation in Mirzachul natural geographical area, $\mathrm{mm}$

\begin{tabular}{|l|c|c|c|c|}
\hline S/n & Station & $\begin{array}{c}2003 \\
\text { ( heavy rain })\end{array}$ & $\begin{array}{c}2007 \\
\text { (arid })\end{array}$ & $\begin{array}{c}\text { A lot on average } \\
\text { annual precipitation }\end{array}$ \\
\hline 1 & Nurata f & 418,3 & 149,9 & 237 \\
\hline 2 & Forish & 421,5 & 132,0 & 241 \\
\hline 3 & Jizzakh & 444,6 & 160,3 & 283 \\
\hline 4 & Mirzachul & 356,2 & 98,7 & 198 \\
\hline
\end{tabular}

Table 1.3 shows that in 2003, the amount of precipitation detected at Nurata, Forish, Jizzakh and Mirzachul meteorological stations was 3 times higher than in 2007, and almost 2 times higher than the average perennial precipitation. This means that the amount of precipitation in a natural geographic area varies over the years.

In the natural geographical area of Mirzachul, the wind direction varies depending on the general circulation of the atmosphere, the relief of the place. In general, the areas surrounding the natural geographic area are more prone to north and northeast winds in winter. In the foothills and on the northern slopes of the Nurata
Mountains (Forish and Jizzakh stations), westerly and southwesterly winds predominate. During the summer months, with the formation of the Central Asian thermal depression, the baric gradient changes from northwest to southwest [20]. Due to this, the direction of air flow also changes.

The influence of winds on the dynamic change of landscapes of Mirzachul natural geographical region is significant. Before we assessed the change in landscapes occurring in a natural geographic region under the influence of wind, the directions of the wind were studied using a wind flower. (See Figure 1.1).

Figure 1.1

Determining wind directions through the wind flower in the natural geographical region of Mirzachul

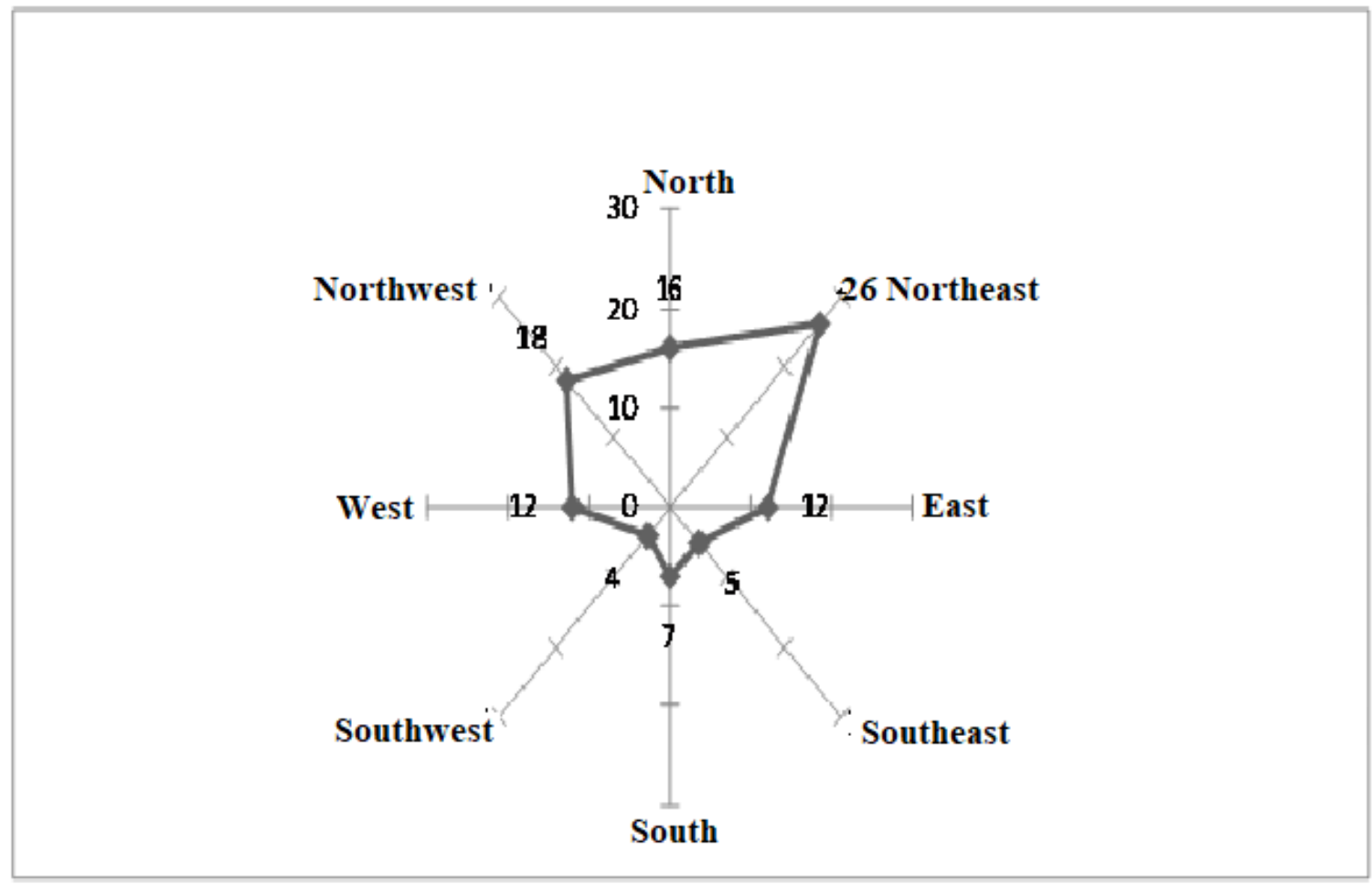

According to the occurrence of winds blowing in the natural geographical area of Mirzachul, it is possible to conditionally divide into wind types depending on the natural conditions of the country and not related. North- west, north and north-east winds blowing in Mirzachul natural geographical region are winds that occur independently of the natural conditions of the natural geographical region. According to local meteorological 
stations (Jizzakh, Dustlik, Yangier and Syrdarya), the average annual wind speed in these directions is around 3-4.6 m / sec.

Examples of winds blowing depending on the natural conditions of the natural geographical area are the breeze-type Aydar-Arnasay lake system between the land and wind-type winds blowing between the Turkestan ridge and its foothills.

Due to the increase in the area of the Aydar-Arnasay lake system (3702 km2) and the volume of water (44.1 $\mathrm{km} 3$ ), the differences in the distribution of solar radiation between the lake and the land are increasing [4; P. 16]. As a result, breeze-type winds blow from the lake to the land during the day and from the land to the lake in the evening. According to the Arnasay hydrometeorological station, wind speeds of breeze type sometimes reach $10-15 \mathrm{~m} / \mathrm{s}$ in spring.

The southern part of the Mirzachul natural geographical region is connected with the Turkestan ridge, and due to changes in pressure between them, mountain-valley winds are observed on some days. Mountain-valley type winds move from the Turkestan ridge to the foothills in the first half of the day, and in the second half of the day, in the opposite direction. The average wind speed in this direction is $1-3 \mathrm{~m} / \mathrm{s}$.

As a result of the study of the direction of winds in the natural geographical area of Mirzachul, it was found that the winds in the north-eastern direction are more frequent (see Table 1.4).

Table 1.4

The direction of winds in the Mirzachul natural geographical area

\begin{tabular}{|c|c|c|}
\hline № & The direction of the wind & Repetition \% \\
\hline 1 & North & 16 \\
\hline 2 & Northeast & 26 \\
\hline 3 & East & 12 \\
\hline 4 & Southeast & 5 \\
\hline 5 & South & 7 \\
\hline 6 & Southwest & 4 \\
\hline 7 & West & 12 \\
\hline 8 & Northwest & 18 \\
\hline
\end{tabular}

Winds blowing from the northeast are causing the salt in the saline soils formed in the Mirzachul natural geographical area to evaporate and re-spread. As a result, the soil composition is degraded and the productivity of agricultural crops is reduced by $15-20 \%$.

Under the influence of wind, the northern and northwestern regions of the natural geographical region are experiencing deflation. The reason is that the area consists of a desert landscape and the level of vegetation cover of the soil is very low. As a result, fine and dry particles of soil are eroded and carried away by the wind and form wind accumulations. Due to wind accumulations, various relief forms of sand - barkhan, dune and sand boundaries are formed in the natural geographical area.

\section{ONCLUSION}

In conclusion, according to botanists, in the Mirzachul natural geographical region, the importance of wind is growing in the direct pollination of plants by $10 \%$ of wind or redistribution of moist air masses in the waters of the Aydar-Arnasay lake system.

\section{EFERENCES}

1. Alibekov L, Alibekova S, Hazarov I, Gudalov M. About some regularities of geosystems degradation in Central Asia. Tatranka Javorina, Slovakia, 2012, Vol 21, № -1, 42-44 p

2. Gudalov M. Foundation of Aydar-Arnasay lakes system and their effects on the environmental landscape. Nature and Science.Volume 17, Number 11 November 25, 2019 USA New York:

3. Gudalov M., Zikirov B. Methods of studying the landscapes around the Aydar-Arnasay lake system. International engineering journal for research \& development. Vol -5 , Issue -7 , 2020 India:.

4. Gudalov M., Zikirov B., Imamova D. Predicting changes in landscares around the AydarArnasay lake system. Accerted in the journal The American of Engineering and Technology. Volume - 02, Issue - 10, October 2020.

5. Gudalov M., Gozieva M. Ways to develor modern ecoturism in the Zamin basin. International engineering journal for research \& development. Vol - 5, Issue - 7, 2020 India:

6. Sharipov Sh, Gudalov M, Shomurodova Sh. Geolologic situation in the Aydar-Arnasay colony and its atropny. Journal of Critical Reviews. Volume 7, Issue 3, 2020 Maleziya Kuala-Lumpur:.

7. Sharipov Sh, Shomurodova Sh, Gudalov M. The 
use of the mountain kars in the tourism sphere in cort and recreation zone of ChimganCharvak. Journal of Critical Reviews. Volume 7, Issue 3, 2020 Maleziya Kuala-Lumpur:. 